\title{
Уголовная ответственность индивидов за совершение международных преступлений
}

\section{Григорович Ю.В. *}

Со второй половины XIX в. можно проследить развитие концепции уголовной ответственности за нарушения международного гуманитарного права. В XX в. стало общим понимание того, что именно деяниями людей, руководящих государствами, совершаются международные деликты и международные преступления, что государство просто используется ими как орудие посягательства на ценности, охраняемые международным правом, и как инструмент причинения вреда другим государствам, его юридическим и физическим лицам.

Необходимость привлечения к ответственности главных руководителей государств за агрессию и другие тяжкие нарушения международного гуманитарного права побудила мировое сообество приступить к формированию института уголовной ответственности индивидов за совершение международных преступлений, единственными субъектами которого являются руководители, должностные лица, служащие и другие агенты государства, отдававшие приказы, исполнявшие эти приказы или иным образом принимавшие участие в деяниях, признаваемых международными преступлениями.

Привлечение к уголовной ответственности руководителей государств-делинквентов и других официальных лиц - пособников и исполнителей преступных приказов этих руководителей и по сей день является исключительно трудным делом по политическим соображениям, из-за отсутствия отлаженных механизмов международного правосудия, а также из-за злоупотребления государствами своим правом на невыдачу преступников.

Правовое регулирование уголовной ответственности индивидов за нарушение законов и обычаев войны фактически берет начало с принятия Гаагской конвенции о законах и обычаях сухопутной войны 1907 г., которая провозгласила, что воюющая сторона «будет ответственна за все действия, совершенные лицами, входящими в состав

\footnotetext{
* Григорович Юлия Владимировна - адъюнкт кафедры прав человека и международного права Московского университета МВД России.
} 
ее военных сил» (ст. III) ${ }^{1}$. Правда, в этой статье акцент делается на то, что воюющее государство несет ответственность за виновные действия лиц, входящих в состав его вооруженных сил. Но государство не может быть субъектом уголовной ответственности за нарушение норм международного гуманитарного права, включая и те, которые указаны в Приложении к этой Конвенции (ст. XXIII-XXVIII). Следует предположить, что воюющие государства - участники названной Конвенции сами должны привлекать к уголовной ответственности лиц, нарушающих законы и обычаи войны, в национальных судах или передавать их в органы международного правосудия ${ }^{2}$.

Как правильно отмечает профессор Ю.М. Колосов, «ответственность государства-делинквента за совершение международных преступлений возникает, в частности, в форме ограничения его юрисдикции в отношении собственных граждан - непосредственных участников совершения международного преступления ${ }^{3}$.

Огромные по масштабам и тяжести военные преступления, совершенные Германией во время Первой мировой войны 1914-1918 гг., сделали насущной проблему привлечения к уголовной ответственности виновных в этих преступлениях.

В соответствии со ст. 227 Версальского договора союзные и объединившиеся державы предъявили Вильгельму II Гогенцоллерну, бывшему императору Германии, «публичное обвинение в высшем оскорблении международной морали и священной силы договора» ${ }^{4}$. Версальский договор предусматривал создание специального Международного трибунала для осуществления правосудия над Вильгельмом II . Однако, как оказалось в действительности, правящие круги Антанты лишь продекларировали готовность наказать руководителей кайзеровской Германии. Сами же опасались судебного процесса над Вильгельмом II, который мог стать для них небезопасным прецедентом в международной практике. В результате Вильгельм II к судебной ответственности так и не был привлечен. К тому же Голландия, куда он сбежал, отказалась выдать его союзникам.

\footnotetext{
1 Международное право в избранных документах. Т. ІІІ. Изд-во ИМО, 1957. С. 42.

2 Котляров И.И. Международное гуманитарное право. М., 2006. С. 255.

${ }^{3}$ Колосов Ю.М. Международная уголовная ответственность физических лиц за международные преступления. См.: Международное право: Учебник. Отв. ред. Ю.М. Колосов, Э.С. Кривчикова. М., 2005. С. 332.

4 Полянский И.И. Международное правосудие и преступники войны. Изд-во АН СССР, 1945. С. 32-49.
} 
Помимо этого ст. 228 Версальского мирного договора наделяла государства-участники правом привлекать к уголовной ответственности перед своими трибуналами немецких граждан, которые нарушили законы и обычаи войны. Однако и эта попытка привлечь индивидов к уголовной ответственности не увенчалась успехом ${ }^{5}$. Германии удалось достичь соглашения о том, что ее подданные будут привлекаться к ответственности только немецким судом. В Лейпциге впоследствии прошло несколько судебных процессов над германскими преступниками, в ходе которых подсудимые были либо оправданы, либо осуждены к незначительным мерам наказания 6 .

Таким образом, западные державы превратили в фарс попытку осудить Вильгельма II, других лиц, виновных в нарушении законов и обычаев войны. Число германских граждан, обвиненных по первому союзническому списку, составило 896 человек; число подсудимых по списку, признанному Германией, составило 45; перед Верховным трибуналом в Лейпциге предстало лишь 12 человек, из которых было осуждено только шесть. По существу положения Версальского договора об ответственности Германии за нарушение законов и обычаев в ходе Первой мировой войны не были реализованы, как того требовала Конвенция 1907 г.

Тем не менее Версальский договор 1919 г. провозгласил наказуемость нарушений законов и обычаев войны и в этом смысле был определенной вехой на пути криминализации таких нарушений.

В Женевских конвенциях «Об улучшении участи раненых и больных в действующих армиях» и «Об обращении с военнопленными», принятых в 1929 г., была закреплена обязанность государств принять соответствующие нормативные акты либо рекомендовать органам законодательной власти ввести в действие соответствующие меры для пресечения нарушений этих конвенций․

Таким образом, в конвенциях было сформулировано прямое требование о привлечении к уголовной ответственности индивидов за нарушения норм этих документов. То есть в международном праве была

5 Трайнин А.Н. Версальский мир и ответственность за преступления войны 1914-1918 гг. / Избранные труды. СПб., 2004. С. 55.

${ }^{6}$ Willis J.F. Prologue to Nuremberg. The politics and Diplomacy of Punishing War Criminals of the First World War. Westport/London, 1982. P. 126-147.

${ }^{7}$ Статья XIX Женевской конвенции об улучшении участи больных и раненых в действующих армиях, прин. 27 июля 1929 г. // League of Nations Treaty Series. Vol. CXVIII. No. 2733, P. 304. 
закреплена концепция так называемой «опосредованной» уголовной ответственности, когда необходимость наступления уголовной ответственности предписывается международным правом, но свое нормативное воплощение положение об ответственности должно найти в национальном праве. Вместе с тем анализ норм Женевских конвенций 1929 г. показывает, что международное предписание осуществлять уголовное преследование на национальном уровне носит достаточно общий характер, поскольку ни в самой статье, ни в тексте конвенции из общего перечня правил не выделены те нормы, нарушение которых должно караться именно уголовным правом. Кроме того, сама формулировка ст. XIX конвенции указывает скорее на рекомендательный, нежели на императивный характер предписания. Следует отметить, что на практике появление такой нормы в международном праве так и не привело к повсеместному введению уголовной ответственности за нарушение положений международного гуманитарного права на национальном уровне.

Наряду с совершенствованием нормативной базы международного гуманитарного права, еще до Второй мировой войны в рамках Лиги наций, а также Ассоциации международного права и Международной ассоциации уголовного права неоднократно предпринимались попытки создать международный уголовный суд. Это привело к принятию в 1937 г. Конвенции о создании Международного уголовного суда, которая, однако, так и не вступила в силу.

Таким образом, до Второй мировой войны международное гуманитарное право прошло путь от установления общего требования соблюдать конвенции до закрепления рекомендации совершенствовать национальное уголовное законодательство для пресечения совершения индивидами нарушений международного гуманитарного права. Но за этот период не было создано международного органа, полномочного рассматривать дела о нарушениях международного гуманитарного права, то есть концепция непосредственной международной уголовной ответственности так и не была реализована на практике.

Реальное воплощение идея наказания военных преступников нашла в ходе и после окончания Второй мировой войны. Решающей силой был Советский Союз, чья принципиальная политика способствовала принятию самых радикальных решений по вопросу о привлечении главных военных преступников стран «оси» к уголовной ответственности.

Компетентные органы Советского Союза в ходе войны вели точный учет преступлений германского фашизма. В этих целях Указом 
Президиума Верховного суда от 2 ноября 1942 г. была учреждена Чрезвычайная комиссия по установлению и расследованию злодеяний немецко-фашистских захватчиков и их сообщников и причиненного ими ущерба гражданам, колхозам, общественным организациям, государственным предприятиям и учреждениям СССР. Материалы Комиссии были приняты за основу при предъявлении на Нюрнбергском процессе обвинений гитлеровцам в совершении злодеяний на территории СССР.

В рамках Объединенных Наций была создана специальная Комиссия по военным преступлениям (United Nations War Crimes Commissions). Во время войны Советский Союз самостоятельно, а также совместно с другими Объединенными Нациями опубликовал ряд нот и заявлений, которые информировали мир о чудовищных преступлениях, совершенных гитлеровцами на временно оккупированных советских территориях, и содержали предупреждения об ответственности за эти преступления 8 . Советский Союз не только первым сформулировал принципы ответственности и наказания военных преступников, но и первым осуществил их на практике. В 1943 г. были проведены судебные процессы над военными преступниками в Харькове и Краснодаре, а затем и в других советских городах: Киеве, Минске, Риге, Ленинграде, Смоленске, Брянске, Великих Луках и Николаеве.

8 августа 1945 г. в Лондоне было подписано Соглашение между Правительствами Союза Советских Социалистических Республик, Соединенных Штатов Америки и Соединенного Королевства Великобритании и Северной Ирландии и Временным Правительством Французской Республики. Основу соглашения составили положения Московской декларации от 30 октября 1943 г. об ответственности гитлеровцев за совершенные зверства, под которой поставили свои подписи руководители СССР, США и Великобритании. В соответствии с данной декларацией в Лондонском соглашении указывалось: «Ничто в настоящем Соглашении не умаляет установленных Московской декларацией положений о возвращении военных преступников в страны, где ими были совершены преступления» (ст. 4)9; «Ничто в насто-

8 Полторак А.И., Савинский Л.И. Вооруженные конфликты и международное право. М., 1976.С. 397.

9 Международное гуманитарное право в документах. Составители Ю.М. Колосов, И.И. Котляров. М.: Московский независимый институт международного права, 1997. С. 519 . 
ящем Соглашении не умаляет компетенции и не ограничивает прав национальных и оккупационных судов, которые уже созданы или будут созданы на любой союзной территории или в Германии для суда над военными преступниками» (ст. 6) ${ }^{10}$.

Необходимость проведения международного суда над гитлеровцами впервые была инициирована Правительством СССР в заявлении «Об ответственности гитлеровских захватчиков и их сообщников за злодеяния, совершаемые ими в оккупированных странах Европы» (14 октября 1942 г.). В нем говорилось: «Советское правительство считает необходимым безотлагательное предание суду специального Международного трибунала и наказание по всей строгости уголовного закона любого из главарей фашистской Германии, оказавшихся уже в процессе войны в руках властей государств, борющихся против гитлеровской Германии».

Учреждение военного трибунала с международным статусом стало возможным во многом благодаря созданию на конференции в Сан-Франциско (апрель-июнь 1945 г.) Организации Объединенных Наций - всемирной организации безопасности, объединившей все миролюбивые государства, которые совместными усилиями оказали достойный отпор фашистской агрессии.

Юрисдикция Международного военного трибунала была определена его Уставом, составлявшим неотъемлемую часть Лондонского соглашения. В ст. 6 Устава Нюрнбергского трибунала были сформулированы основные международные преступления, совершенные фашистской Германией в период Второй мировой войны, и дана их классификация.

Первая группа - преступления против мира - включает в себя планирование агрессивной войны: это работа штабов по определению сроков войны, сил и средств, объектов первого, второго и т.д. ударов, направления этих ударов (например, план «Барбаросса»). Затем подготовка войны - понятие, включающее составление планов, перестройку экономики на военный лад, развертывание вооруженных сил, моральную подготовку населения, воспитание его в духе ненависти к коммунизму, нравственное растление путем воспитания в духе вседозволенности, насилия. И нацизм воспитывал немцев в духе превосходства арийской расы над всеми другими народами ${ }^{11}$.

10 Там же. С. 519.

11 Карпец И.И. Международная преступность. М.: Наука, 1988. С. 99. 
Развязывая Вторую мировую войну, гитлеровцы заявили, что они стремятся к уничтожению целых народов. «Надо любыми средствами, - говорил Гитлер, - добиваться того, чтобы мир был завоеван немцами. Если мы хотим создать нашу великую Германскую империю, мы должны прежде всего вытеснить и истребить славянские народы - русских, поляков, чехов, словаков, болгар, украинцев, белорусов. Нет никаких причин не сделать этого». Выработанные и тщательно культивировавшиеся в течение многих лет до войны фашистские расовые теории послужили «теоретическим обоснованием» истребления гитлеровцами в ходе Второй мировой войны многих миллионов людей ${ }^{12}$.

Статья 6 Устава Нюрнбергского трибунала к преступлениям против мира относит развязывание или ведение агрессивной войны или войны в нарушение международных договоров, соглашений или заверений. Участие в общем плане или заговоре, направленных к осуществлению любого из указанных действий, которые в уголовном праве называются соучастием, также являются преступлениями против мира.

Вторую группу преступлений составляют военные преступления. Возникновение понятия «военное преступление» восходит к кодексу Ф. Либера, принятому правительством США во время гражданской войны 1861-1865 гг. («Инструкции для командования армиями Соединенных Штатов на полях сражений»). Кодекс предусматривал введение на оккупированной территории законов и обычаев военного времени, которые содержали обязательства как для оккупированной, так и для оккупирующей стороны (ст. 13), и должны были использоваться для пресечения военных и уголовных преступлений (ст. 44, 47)13.

Согласно ст. 6 Устава Нюрнбергского трибунала, к военным преступлениям относятся нарушения законов или обычаев войны, а именно: убийства, истязания или увод в рабство или для других целей гражданского населения оккупированной территории; убийства или истязания военнопленных или лиц, находящихся в море; убийства заложников; ограбление общественной или частной собственности; бессмысленное разрушение городов и деревень; разорение, не оправданное военной необходимостью, и другие преступления.

12 Андрюхин М.Н. Геноцид - тягчайшее преступление против человечества. М., 1961.C. 61.

${ }^{13}$ См.: Schindler S., Toman J. The Laws of Armed Conflict. Leyden-Genève, 1973. P. 5 etc. 
К третьей группе преступлений относятся преступления против человечности 14 : убийства, истребление, порабощение, ссылки и другие жестокости, совершенные в отношении гражданского населения до или во время войны, или преследования по политическим, расовым или религиозным мотивам с целью осуществления или в связи с любым преступлением, подлежащим юрисдикции трибунала, независимо от того, являлись ли эти действия нарушением внутреннего права страны, где они были совершены, или нет ${ }^{15}$.

Согласно Московской декларации от 2 ноября 1943 г. трибунал был учрежден для наказания только главных военных преступников европейских стран оси. К ним относились виновники таких тягчайших преступлений, совершение которых «не связано с определенным географическим местом». Главными военными преступниками являлись также вдохновители и организаторы бандитизма, т.е. лица, которые занимали руководящие посты в составе правительства или непосредственно подчиненных ему органов либо в нацистской партии и принимали участие в совершении преступлений против мира, военных преступлений и преступлений против человечности. Устав Международного военного трибунала устранял всякую возможность

14 Впервые термин «преступление против человечности» был использован в Декларации 1915 г. правительств Англии, России и Франции для квалификации резни армян в Турции, что по сегодняшним критериям подпадает под понятие геноцида. В дальнейшем понятие преступления против человечности стало частично совпадать с понятием военного преступления и вообще связывалось с наличием вооруженного конфликта. Современная трактовка преступления против человечности весьма широка, включает в себя широкий круг массовых злодеяний против личности и достоинства человека независимо от того, в мирное или военное время такие злодеяния совершены. Термин «человечность» еще с тех времен, когда Нюрнбергский трибунал впервые ввел его в правовой оборот, вызывает немалые трудности у русских переводчиков. Дело в том, что по-английски слово "humanity" можно перевести и как «человечность», и как «человечество»; отсюда разнобой в отечественной юридической литературе, который не преодолен и по сей день. И трудно высказывать свое мнение на тему о том, какой из вариантов предпочтительнее. Возможно, омонимия понятий «человечность» и «человечество», существующая в английском языке, знаменательна и полна смысла. Человечность - понятие, относящееся скорее к нравственности, чем к юриспруденции. И посему преступление против человечности - это всегда преступление против человечества в целом, против всего людского рода, несмотря на то что объектом этого преступления, как правило, становится конкретная группа людей. Возможно, в русском переводе необходимо воспроизводить английский термин "humanity" в обоих его смыслах: «преступление против человечности (человечества)».

15 Международное гуманитарное право в документах. Московский независимый институт международного права. Указ. соч. С. 519. 
рассматривать членов правительства как лиц, не подлежащих уголовной ответственности за проводимые ими мероприятия и несущих лишь политическую ответственность. Статья 7 Устава гласит: «Должностное положение подсудимых, их положение в качестве глав государства или ответственных чиновников различных правительственных ведомств не должно рассматриваться как основание к освобождению от ответственности или смягчению наказания».

Нюрнбергский процесс имеет огромное общественно-политическое значение. Он стал историческим событием прежде всего как торжество Закона перед нацистским беззаконием. Нюрнбергский процесс разоблачил человеконенавистническую сущность германского фашизма, его планы уничтожения целых государств и народов, запредельную бесчеловечность и жестокость, абсолютную аморальность, показал крайнюю опасность фашизма для всего человечества. Нюрнбергский процесс был первым в истории событием подобного рода.

В Уставе Международного военного трибунала были сформулированы не известные до того времени международные преступления, которые затем прочно вошли в международное право и национальное законодательство многих государств. Впервые к уголовной ответственности были привлечены официальные лица, причастные к планированию, подготовке и развязыванию агрессивных войн. Впервые было признано, что положение главы государства, ведомства или армии, а также исполнение распоряжений правительства или преступного приказа не освобождают от уголовной ответственности.

Приговор Нюрнбергского трибунала получил международное одобрение в резолюции Генеральной Ассамблеи ООН 95 (I) от 11 декабря 1946 г., озаглавленной «Подтверждение принципов международного права, признанных Статутом Нюрнбергского трибунала». В ней отмечалось, что Генеральная Ассамблея принимает к сведению Соглашение об учреждении Международного военного трибунала для привлечения к ответственности и наказания главных военных преступников стран оси в Европе, подписанное в Лондоне 8 августа 1945 г., и приложенный к нему Статут, а равно и то обстоятельство, что аналогичные принципы были приняты в Статуте Международного военного трибунала для суда над главными преступниками на Дальнем Востоке, провозглашенном в Токио 19 января 1946 г., подтверждает принципы международного права, признанные Статутом Нюрнбергского трибунала и нашедшие выражение в решении трибунала ${ }^{16}$.

16 Нюрнбергский процесс. Т. 7. М.: Госюриздат, 1961. С. 550. 
Нюрнбергский приговор явился огромным вкладом в развитие прогрессивных принципов международного права. Вслед за ним был принят ряд новых актов в области защиты прав человека в период вооруженных конфликтов, в частности Конвенция о предупреждении преступлений геноцида и наказании за него от 9 декабря 1948 г. и Конвенция о пресечении преступления апартеида и наказании за него om 30 ноября 1973 г., в которых говорится о наказании физических лиц соответственно за преступления геноцида и апартеида.

Кроме того, четыре Женевские конвенции о защчите жертв войны 1949 г. ввели такую новую правовую категорию, как «серьезные нарушения конвенций», совершенные во время вооруженных конфликтов международного характера, которые Дополнительным протоколом I квалифицируются как военные преступления (ст. 85 п. 5). Женевские конвенции возложили на государства обязанность осуществлять преследование таких преступлений.

В 1977 г. были приняты два Дополнительных протокола к Женевским конвенциям 1949 г. В Дополнительном протоколе I вопрос об уголовной ответственности физических лиц за нарушение норм международного гуманитарного права нашел свое дальнейшее развитие. В нем закреплена норма о том, что воюющие стороны несут ответственность за все действия, совершаемые лицами, входящими в состав их вооруженных сил (ст. 91).

Что касается вооруженных конфликтов немеждународного характеpa, то в п. 1 ст. 6 Дополнительного протокола II, озаглавленной «Уголовное преследование», отмечается, что «настоящая статья применяется к судебному преследованию и наказанию за уголовные правонарушения, связанные с вооруженным конфликтом».

В Римском статуте Международного уголовного суда также закреплены положения об индивидуальной уголовной ответственности лиц за международные преступления. Названный Статут применяется в равной мере ко всем лицам вне зависимости от занимаемой ими должности: главы государства или правительства, члена правительства или парламента, избранного представителя или должностного лица правительства (ст. 27).

Конвенция о защите культурных цеенностей в случае вооруженного конфликта 1954 г., которая предписывает государствам-участникам обеспечить соблюдение норм этой конвенции, в том числе и путем при- 
нятия соответствующих уголовно-правовых норм ${ }^{17}$ и Второй протокол к ней 1999 г. В 1980 г. были приняты Конвенция о запрещении или ограничении применения конкретных видов обычного оружия, которые могут считаться наносящими чрезмерные повреждения или имеющими неизбирательное действие, и протокольк ней. В соответствии с этими нормативными актами было запрещено применение оружия, основное действие которого заключается в нанесении повреждений осколками, не обнаруживаемыми в человеческом теле с помощью рентгеновских лучей, применение мин, мин-ловушек и других устройств, указанных в Протоколе II с поправками, внесенными 3 мая 1996 г, зажигательного оружия и ослепляющего лазерного оружия. В Протоколе II получила свое нормативное закрепление обязанность государств ввести уголовную ответственность за нарушения положений этого документа 18 .

Все вышеперечисленные Конвенции являются источниками международного гуманитарного права, которые предусматривают уголовную ответственность индивидов за совершение международных преступлений. Россия (Советский Союз), являясь участником договоров, относящихся к международному гуманитарному праву, взяла на себя обязательства «ввести в действие законодательство, необходимое для обеспечения эффективных уголовных наказаний для лиц, совершивших или приказавших совершить те или иные серьезные нарушения...» (ст. 49, 50, 129, 146 соответственно I-IV Женевских конвенций). Выполнить эти обязательства, то есть имплементировать нормы международного права в национальное законодательство, Россию обязывает императивный принцип международного права добросовестного выполнения договорных обязательств, ст. 15 п. 4 Конституции РФ, положения, закрепленные в Федеральном законе РФ «О международных договорах Российской Федерации» 1995 г. (преамбула, ст. 5, 31, 32) ${ }^{19}$, а также Постановление Пленума Верховного суда РФ «О применении судами общей юрисдикции общепризнанных принципов и норм международного права и международных договоров РФ» от 10 октября 2003 г.

17 Статья 28 Гаагской конвенции о защите культурных ценностей в случае вооружённого конфликта 1954 г.// Международное гуманитарное право в документах - М.: Московский независимый институт международного права, 1997 г. С. 434.

18 Статья 14 Протокола о запрещении или ограничении применения мин, мин-ловушек и других устройств с поправками, внесенными 3 мая 1996 г.

19 Котляров И.И. Нюрнбергский процесс и прогрессивное развитие международного гуманитарного права // Московский журнал международного права. 2006. № 4. С. 103. 
Однако, на наш взгляд, российское законодательство об уголовной ответственности за нарушения международного гуманитарного права не в полной мере соответствует нормам международного права. Так, нарушениям международного гуманитарного права в Уголовном кодексе РФ посвящена лишь одна ст. 356 «Применение запрещенных средств и методов ведения войны, которая не охватывает всех 50 серьезных нарушений, указанных в Женевских конвенциях о защите жертв войны 1949 г. и в Дополнительных протоколах I, II к ним 1977 г., в Конвенции о защите культурных ценностей в случае вооруженного конфликта 1954 г. и во Втором протоколе к ней 1999 г.

В названии статьи неоправданно объединены достаточно объемные по своему содержанию и совершенно различные по значению понятия «средства» и «методы» ведения войны. Их содержание может быть раскрыто только после обращения к другим нормативным актам - международным договорам по международному гуманитарному праву, обязательным для Российской Федерации. И если к запрещенным средствам ведения войны обычно относят оружие, предназначенное для поражения живой силы и объектов противника, и проблем в толковании этого понятия не возникает ${ }^{20}$, то в теории международного гуманитарного права и нормативных документах отсутствуют единые подходы к пониманию «методов» ведения войны, что может ввести в затруднительное положение правоприменительные органы при квалификации противоправных деяний по этой статье.

В части 1 статьи неоправданно широко представлен объект преступления, включающий разнородные, несопоставимые по тяжести совершаемого посягательства: а) против жертв войны; б) на национальное имущество; в) тут же закреплено достаточно неопределенное положение, касающееся применения запрещенных «средств и методов» ведения войны, о чем говорилось выше.

Таким образом, Россия лишь символически имплементировала Женевские конвенции и Дополнительные протоколы к ним, и результаты такого «правотворчества» не могут быть эффективно использованы правоприменительными органами в своей практической работе для реали-

20 См., например: Давид Э. Принципы права вооруженных конфликтов. МККК. М., 2000. C. 207-305. 
зации положений международного гуманитарного права об индивидуальной ответственности лиц, совершивших военные преступления ${ }^{21}$.

Индивидуальная ответственность за серьезные нарушения международного гуманитарного права получила свое закрепление в международных договорах не путем введения конкретных санкций за преступные деяния, а через запрещение определенного поведения и признание государством обязанности преследовать такие нарушения в соответствии с национальным законодательством.

Такая схема давала очевидные сбои и не справлялась с задачей привлечения к уголовной ответственности военных преступников, что привело к необходимости создания международных уголовных судов, таких как Международный трибунал по бывшей Югославии, Международный трибунал по Руанде, Специальный суд по Сьерра-Леоне. В 1998 г. был принят и в 2002 г. вступил в силу Римский статут, учредивший постоянный судебный орган для преследования виновных в совершении международных преступлений - Международный уголовный суд (далее - МУС).

Учреждение МУС явилось серьезнейшим прорывом в устранении безнаказанности международных преступлений. Дополняющий национальные органы уголовной юстиции МУС призван осуществлять уголовное преследование в тех случаях, когда внутригосударственная судебная система по каким-либо причинам оказывается не в состоянии либо не желает наказать виновных. При этом юрисдикция МУС ограничивается самыми серьезными преступлениями, вызывающими озабоченность всего международного сообщества.

Статут МУС использует различные понятия для определения преступлений, подпадающих под юрисдикцию Суда. В частности: серьезные преступления - grave crimes, международные преступления - international crimes ${ }^{22}$, наиболее серьезные преступления, вызывающие озабоченность всего международного сообщества - most serious crimes of concern to the international community as a whole 23 . В любом случае речь идет о преследовании деяний, предусмотренных ст. 5. При этом данная статья не отражает какой-либо формальной иерархии этих де-

21 Котляров И.И. Нюрнбергский процесс и прогрессивное развитие международного гуманитарного права // Московский журнал международного права. 2006. № 4. С. 105.

22 См.: Preamble of the Rome Statute of the International Criminal Court - A Commentary// Cassese A, Gaeta P. Jones J. Oxford University Press. 2002.

23 Preamble and article 5 of the Rome Statute of the International Criminal Court - A Commentary // Cassese A., Gaeta P., Jones J. Oxford University Press. 2002. 
яний, основанной на том или ином критерии (например, тяжести преступления). Все указанные преступления в равной мере представляют собой серьезнейшую опасность для международного сообщества, их совершение должно влечь уголовную ответственность, а виновные не могут оставаться безнаказанными.

Согласно ст. 5 Статута, МУС обладает юрисдикцией в отношении четырех категорий международных преступлений:

1. Преступление геноцида, то есть любого из деяний, совершаемых с намерением уничтожить полностью или частично какую-либо национальную, этническую, расовую или религиозную группу как таковую ${ }^{24}$.

2. Преступления против человечности, т.е. деяния, которые совершаются в рамках широкомасштабного или систематического нападения на любых гражданских лиц, если такое нападение совершено сознательно 25 .

3. Военные преступления - серьезные нарушения Женевских конвенций от 12 августа 1949 г., другие серьезные нарушения законов и обычаев войны ${ }^{26}$.

Квалифицирующим признаком военных преступлений является совершение их в рамках плана или политики или при крупномасштабном совериении таких преступлений.

24 Речь идет о таких деяниях, как: а) убийство членов такой группы; б) причинение серьезных телесных повреждений или умственного расстройства членам такой группы; в) предумышленное создание для какой-либо группы таких жизненных условий, которые рассчитаны на ее полное или частичное физическое уничтожение; г) меры, рассчитанные на предотвращение деторождения в среде такой группы; д) насильственная передача детей из одной человеческой группы в другую.

25 Убийство; истребление; порабощение; депортация или насильственное перемещение населения; заключение в тюрьму или другое жестокое лишение физической свободы в нарушение основополагающих норм международного права; пытки; изнасилование, обращение в сексуальное рабство, принуждение к проституции и др.

26 Умышленное убийство; пытки или бесчеловечное обращение, включая биологические эксперименты; умышленное причинение сильных страданий или серьезных телесных повреждений или ущерба здоровью; взятие заложников и др., совершенные в период международных вооруженных конфликтов, а также в ходе вооруженных конфликтов немеждународного характера (серьезные нарушения ст. 3, общей для четырех Женевских конвенций, а именно: любое из деяний, совершенных в отношении лиц, не принимающих участия в военных действиях, включая военнослужащих, сложивших оружие, и лиц, выведенных из строя в результате болезни, ранения, содержания под стражей или по любой другой причине, а также другие серьезные нарушения законов и обычаев войны). 


\section{4. Преступление агрессии 27.}

Теперь актуальным представляется через призму Римского статута МУС посмотреть на отражение его норм в УК РФ. Из названных групп преступлений, подпадающих под юрисдикцию МУС, в УК РФ нашли закрепление две группы: геноцид и преступление агрессии.

1. Формулировка геноцида, приводимая в ст. 6 Римского статута МУС и в ст. II Конвенции о предупреждении преступления геноцида и наказании за него 1948 г. полностью воспроизводится в ст. 357 УК РФ, устанавливающей уголовную ответственность за геноцид, и не вызывает каких-либо сомнений. Нормы УК РФ о преступлении геноцида, подпадающего под юрисдикцию МУС, являются совместимыми с Римским статутом, и в случае ратификации Статута каких-либо имплементационных действий в этой части не требуется.

2. Что касается преступления агрессии, то, хотя в Римском статуте оно лишь названо, а определение еще не сформулировано, ст. 353 УК РФ «Планирование, подготовка, развязывание или ведение агрессивной войны» частично воспроизводит п. «а» ст. 6 Устава Международного военного трибунала для суда и наказания главных военных преступников европейских стран оси 1945 г. В нынешних условиях формулировка этого преступления не соответствует существующим международно-правовым документам в этой области, например «Определению агрессии», принятому XXIX сессией Генеральной Ассамблеи ООН в 1974 г.

В то же время, например, в Федеральном конституционном законе РФ «О военном положении» 2002 г. (с оговоркой «для целей настоящего Федерального конституционного закона») используется названное определение агрессии.

Подписанием Римского статута МУС Россия как «демократическое федеративное правовое государство...» (ст. 1 Конституции РФ) политически подтвердила свою приверженность тому, что самые серьезные преступления, вызывающие озабоченность всего международного сообщества, не должны оставаться безнаказанными, и их расследование должно обеспечиваться мерами, принимаемыми на национальном уровне и в процессе активизации международного сотрудничества. В силу этого было бы правильным и последовательным шагом осуществление

27 Суд осуществляет юрисдикцию в отношении преступления агрессии после того, как будет принято положение, содержащее определение агрессии в соответствии со ст. 121 и 123 Римского статута Международного уголовного суда. 
комплексного приведения уголовного законодательства РФ в соответствие с Женевскими конвенциями о защите жертв войны, Дополнительными протоколами к ним и Римским статутом МУС, а также присоединением к последнему.

\section{Criminal Responsibility of Individuals for Committing International Crimes \\ (Summary)}

\section{Julia V. Grigorovich*}

The article examines the development of the international criminal responsibility of individuals before and after the Second World War. Attention is paid to the Nuremberg's principles for international humanitarian law. Regulations of international humanitarian law in criminal legislation of Russian Federation are also considered. Modern conditions of the institute of criminal responsibility of individuals for committing international crimes are examined in connection with acceptance of the Roman statute of the International criminal court. The article suggests a comparative analysis of crimes, which fall under jurisdiction of the international criminal court and criminal legislation of Russian Federation.

\footnotetext{
* Julia V. Grigorovich - post-graduate student of the Chair of human rights and International Law of the Moscow University of the Ministry of Internal Affairs of Russia.
} 